Васютин Игорь Сергеевич, аспирант кафедры «Строительство инженерных сооружений и механика», Рязанский государственный агротехнологический университет имени П.А. Костычева. Россия.

390044, г Рязань, ул. Костычева, 1.
Тел.: (4912) 35-88-31.

Ключевые слова: картофель; сохранность; картофелехранилище; размер воздуховода; шаг планок каркаса; зазоры; вентиляция.

\title{
IMPROVING THE VENTILATION SYSTEM OF THE WAREHOUSE BY MEANS OF RENOVATING THE AIR DUCT
}

Borychev Sergey Nikolaevich, Doctor of Technical Sciences, Professor, Head of the chair "Construction of Engineering Structures and Mechanics”, Ryazan State Agrotechnological University named after P.A. Kostychev. Russia.

Uspenskiy Ivan Alekseevich, Doctor of Technical Sciences, Head of the chair "Technical Exploitation of Transport", Ryazan State Agrotechnological University named after P.A. Kostychev. Russia.

Kostenko Mikhail Yurievich, Doctor of Technical Sciences, Associate Professor of the chair "Metal Technology and Machinery Repair", Ryazan State Agrotechnological University named after P.A. Kostychev. Russia.

Makarov Valentin Alekseevich, Doctor of Technical Sciences, Chief Researcher, VNIIS. Russia.

Murog Igor Alexandrovich, Doctor of Technical Sciences, Professor, Ryazan Institute (branch) of the University of Mechanical Engineering (MAMI). Russia.

Koloshein Dmitry Vladimirovich, Post-graduate of the chair "Construction of Engineering Structures and Mechanics", Ryazan State Agrotechnological University named after P.A. Kostychev. Russia.

Vasyutin Igor Sergeevich, Post-graduate of the chair "Construction of Engineering Structures and Mechanics", Ryazan State
Agrotechnological University named after P.A. Kostychev. Russia.

Keywords: potato; potato warehouse; air duct size; structural battens spacing; gaps; ventilation.

The safety of the potato depends on the ventilation equipment. It is possible to store potato for up to 8 months with the help of microclimate created with the help of ventilation inside the bulk of agricultural products. However, the distribution of venting air from the ducts to the bulk is uneven. Due to this, some foci of self-warming inside the bulk appear which leads to potatoes damage at the storage stage. The analysis of the methods used to study air filtration parameters in bulk layers confirmed that changes in pores of the layer are quite a challenge. Theoretical studies have established the dependence of the day-light area ratio on parameters of the improved air duct. Analysis of the obtained dependence showed that the gap is $20 \mathrm{~mm}$ for battens sized $40 \times 40 \mathrm{~mm}$ and the the day-light area ratio is more than 0.167. Later, in the course of experimental studies, it was found that the pressure losses from the fan depend on the losses in the duct itself, on the basis of which the head loss formula in the ventilation system of the potato warehouse was obtained.

удк 637.34

\section{ИЗУЧЕНИЕ ЗЕРНИСТОГО ТВОРОГА В ПРОЦЕССЕ ФЕРМЕНТАЦИИ}

\author{
ГАЛСТЯН Бардух Сарибекович, Шушинский технологический университет
}

Статъя посвящена использованию в пищевых целях молочной сыворотки и составляющих ее частиц, в частности белка, с иелью улучшения выхода молочного белка, усиления его функциональных свойств, увеличении роли белка в питании человека.

Введение. Комплексная переработка всех составляющих частиц молока является стимулом для повышения эффективности молокопроизводства [1]. С этой точки зрения, в производстве молочных продуктов большую ценность приобретают вопросы по эффективному использованию молочной сыворотки и составляющих ее частиц.

В последние годы в сырном производстве наблюдается тенденция использования сывороточного белка в молоке $[3,5]$. Развитие исследований в данном направлении характеризуется следующими тремя идеями: улучшить выход молочного белка, усилить его функциональные свойства, увеличить роль белка в еде человека.

Таким образом, использование сывороточных белков в молочных продуктах увеличит биологическую ценность этих продуктов, что связано с более высоким содержанием незаменимых аминокислот, а также эффективно будут использоваться основные составные части молока.

Цель статьи - решение вышеупомянутых вопросов является актуальным и требует дальнейшего изучения.

Методика исследований. В производстве зернистого творога творожное зерно получают из обезжиренного молока методом кислотносычужного свертывания с дальнейшей переработкой полученного сгустка. Во время подогрева зерна значительная часть кисломолочных бактерий разрушается. Из-за этого готовый продукт наделен недостаточно выраженным кисломолочным вкусом и запахом.

Полученные из творожной сыворотки сывороточно-белковый сгусток и технология переработки зернового творожного продукта из обезжиренного молока способствуют эффективному использованию вторичного молочного сырья, 
увеличивают производство творога и позволяют увеличить его биологическую и пищевую ценность за счет полного обогащения белком, а также повышают экономическую эффективность [2, 4].

Чтобы определить оптимальное соотношение концентрата сывороточного белка (КСБ) и обезжиренного молока, мы провели три экспериментальных режима производства:

1) соотношение КСБ и обезжиренного молока 2:1;

2) соотношение КСБ и обезжиренного молока $1: 1$;

3) соотношение КСБ и обезжиренного молока $1: 2$.

Испытательные и контрольные (из обезжиренного молока) образцы творога были изготовлены по обычной технологии в идентичных условиях. В первом случае производства творога титрируемая кислотность смеси была высокой, и в результате продукт стал довольно кислым, что было подтверждено во время органолептических исследований. Во время производства творога по варианту 3 процесс сгустки продлевается на $35 \%$ по сравнению с вариантом 2 . Количество незаменимых аминокислот в 1, 2 и 3 вариантах экспериментального творога соответственно от общего количества аминокислот составляло $44,5 \pm 2,0 ; 68,6 \pm 3,1$ и $69,2 \pm 2,7 \%$, тогда как в контрольных образцах этот показатель составлял $38,4 \pm 1,7 \%$.

Согласно органолептическим показателям образцы творога варианта 2 были самыми лучшими, при такой комбинации КСБ и обезжиренного молока получался сбалансированный и полный аминокислотного состава продукт.

Творожное зерно с целью обогащения кисломолочными бактериями и ее ферментативными составляющими было смешано с ферментированными сливками, которое заквашивалось бактериальной закваской. Контролируемый 3\%-й творог был изготовлен в соответствии с утвержденными техническими условиями из обезжиренного молока и $10 \%$-х сливок.

В основе ферментации творожного зерна лежит диффузионно-осмотический процесс между водной частью творожного зерна и средой ферментирования (сливки). В результате этих процессов масса белка имеет биологически активную среду, обогащенную бактериями, их ферментативными системами и жизненно важными функциями. Интенсивность и ориентация диффузионно-осмотических и кислородных процессов зависят от условий их процесса (температура и продолжительность процесса, ферментационная среда и жировая масса, физико-химический состав и среда творожного зерна, а также ряд других факторов).

Исследования позволили улучшить технологию творожного зерна и получить новый тип диетического творога.

Была проведена серия экспериментов по исследованию влияния массы жира на образование творожных продуктов. Ферментированные сливки кислотностью $30,0 \pm 1,0{ }^{\circ} \mathrm{T}$ смешивали с творожным зерном до насыщения творожного продукта жиром $3 \pm 0,1 \%$.

Результаты исследований. В табл. 1 приведены результаты исследований массовой доли жира в сливках по физико-химическим показателям творожного продукта после 12 ч консервации.

Анализ табл. 1 показывает, что в условиях ферментации, когда массовая доля жира увеличивается с 10 до 30 \%, процесс ферментации замедляется. При этом изменяется состав творожного продукта: так массовая доля белка уменьшается на 4,6 \%, массовая доля влаги составляет 10,1 \%, массовая доля жира увеличивается в 3 раза.

Изменения состава творожного зерна, произведенного под воздействием ферментации и изменения физико-химических свойств, оказали значительное влияние на его органолептические показатели (табл. 2).

Как видно из табл. 2, самую высокую органолептическую оценку имеет образец, который был произведен из сливок с массовой долей жира $10 \%$, которые в основном отличались по консистенции и внешнему виду. Параллельно увеличению массовой доли жира в ферментационной среде зерно разрушалось и смазывалось, продукт приобретал пастообразную консистенцию, не свойственную зернистому творогу.

Заключение. Принимая во внимание результаты исследований, была утверждена оптимальная доза массовой доли жира $(10,0 \pm 0,1 \%)$ и

Таблица 1

Воздействие массовой доли жира сливок на физико-химические показатели творожного продукта

\begin{tabular}{|c|c|c|c|c|}
\hline \multirow{3}{*}{ Показатель } & \multicolumn{4}{|c|}{ Массовая доля жира, \% } \\
\hline & проверочный & \multicolumn{3}{|c|}{ экспериментальный } \\
\hline & 10,0 & 10,0 & 20,0 & 30,0 \\
\hline Массовая доля белка, \% & $12,5 \pm 0,36$ & $13,6 \pm 0,40$ & $13,2 \pm 0,38$ & $13,0+0,34$ \\
\hline Массовая доля влажности, \% & $77,5 \pm 1,4$ & $78,4+1,4$ & $75,4 \pm 1,2$ & $71,2+1,2$ \\
\hline Массовая доля масла, \% & $3,0 \pm 1,0$ & $3,0 \pm 0,09$ & $6,4+0,16$ & $9,2 \pm 0,25$ \\
\hline Титрируемая кислотность К & $80,0 \pm 2,5$ & $150,0 \pm 4,5$ & $135,0+4,0$ & $110,0+3,5$ \\
\hline Активная кислотность, рН & & & & \\
\hline
\end{tabular}


Органолептические показатели ферментированного творожного зерна в зависимости от массовой доли жира, балл, в сливках

\begin{tabular}{|c|c|c|c|}
\hline \multirow{2}{*}{ Показатель } & \multicolumn{3}{|c|}{ Массовая доля жира, \% } \\
\hline & 10,0 & 20,0 & 30,0 \\
\hline Вкус и запах & $\begin{array}{l}\text { Чистый, молочно-кислотный } \\
(5,0 \pm 0,5)\end{array}$ & $\begin{array}{l}\text { Чистый, молочно-кислотный } \\
(5,0 \pm 0,5)\end{array}$ & $\begin{array}{c}\text { Слабовыраженный } \\
(4,0 \pm 0,5)\end{array}$ \\
\hline $\begin{array}{l}\text { Внешний вид и консис- } \\
\text { тенция }\end{array}$ & $\begin{array}{l}\text { Неоднородный, равномерный } \\
\text { четко выраженный, с зернами } \\
\text { покрытыми жиром }(3,0 \pm 0,5)\end{array}$ & $\begin{array}{c}\text { Неоднородный, равномерный } \\
\text { четко выраженный, с зерна- } \\
\text { ми покрытыми сливками, } \\
\text { с небольшим помутнением } \\
\text { зерна }(2,0+0,5)\end{array}$ & $\begin{array}{c}\text { Пастообразная, } \\
\text { смазывающаяся } \\
\text { консистенция }(1,5 \pm 0,5)\end{array}$ \\
\hline Цвет & $\begin{array}{c}\text { От белого до светло-желтого, со } \\
\text { светло-желтоватыми тонами } \\
(1,0+0,5)\end{array}$ & $\begin{array}{c}\text { От белого до светло-желтого, } \\
\text { со светло-желтоватыми тонами } \\
(1,0+0,5)\end{array}$ & $\begin{array}{l}\text { От белого до светло-жел- } \\
\text { того, со светло-желтова- } \\
\text { тыми тонами }(1,0+0,5) \\
\end{array}$ \\
\hline Ценовая оценка, балл & $(9,0 \pm 0,5)$ & $(8,0 \pm 0,5)$ & $(7,5 \pm 0,5)$ \\
\hline
\end{tabular}

Таблица 3

\section{Воздействие титрируемой кислотности сливок на физико-химические показатели творожного продукта}

\begin{tabular}{|l|c|c|c|}
\hline \multirow{2}{*}{ Показатель } & \multicolumn{3}{|c|}{ Массовая доля жира, \% } \\
\cline { 2 - 4 } & $20 \pm 2$ & $30 \pm 2$ & $50 \pm 2$ \\
\hline Титрируемая кислотность, ${ }^{\circ} \mathrm{T}$ & $134,0 \pm 4,0$ & $150,0 \pm 4,5$ & $175,0 \pm 5,5$ \\
\hline Активная кислотность $\mathrm{pH}$ & $4,82 \pm 0,47$ & $4,57 \pm 0,32$ & $4,38+0,24$ \\
\hline
\end{tabular}

Таблица 4

Органолептические показатели ферментированного творожного зерна в зависимости от содержания массовой доли жира в сливках

\begin{tabular}{|c|c|c|c|}
\hline \multirow{2}{*}{ Показатель } & \multicolumn{3}{|c|}{ Титрируемая кислотность, ${ }^{\circ} \mathrm{T}$} \\
\hline & $20 \pm 2$ & $30 \pm 2$ & $40 \pm 2$ \\
\hline Вкус и запах & Слабовыраженный $(4,0 \pm 0,5)$ & $\begin{array}{l}\text { Чистый, молочно-кислотный } \\
(5,0 \pm 0,5)\end{array}$ & $\begin{array}{c}\text { Лишний кислый вкус } \\
(4,0 \pm 0,5)\end{array}$ \\
\hline $\begin{array}{l}\text { Внешний вид } \\
\text { и консистенция }\end{array}$ & $\begin{array}{c}\text { Неоднородный, равномерный } \\
\text { четко выраженный, с зернами } \\
\text { покрытыми сливками }(3,0 \pm 0,5)\end{array}$ & $\begin{array}{c}\text { Неоднородный, равномерный } \\
\text { четко выраженный, с зернами } \\
\text { покрытыми сливками }(3,0 \pm 0,5)\end{array}$ & $\begin{array}{c}\text { Неоднородный, равномерный } \\
\text { четко выраженный, с зернами } \\
\text { покрытыми сливками, } \\
\text { С небольшим помутнением } \\
\text { зерна }(3,0 \pm 0,5)\end{array}$ \\
\hline Цвет & $\begin{array}{c}\text { От белого до светло-желтого, со } \\
\text { светло-желтоватыми тонами } \\
(1,0+0,5) \\
\end{array}$ & $\begin{array}{c}\text { От белого до светло-желтого, со } \\
\text { светло-желтоватыми тонами } \\
(1,0+0,5) \\
\end{array}$ & $\begin{array}{c}\text { От белого до слабо желтого, } \\
\text { со светло-желтоватыми тона- } \\
\text { ми }(1,0+0,5)\end{array}$ \\
\hline $\begin{array}{l}\text { Ценовая оценка, } \\
\text { балл }\end{array}$ & $(8,0 \pm 0,5)$ & $(9,0 \pm 0,5)$ & $(7,0 \pm 0,5)$ \\
\hline
\end{tabular}

кислотности $\left(30,0 \pm 2,0^{\circ} \mathrm{T}\right)$ в ферментационной среде.

Мы также исследовали влияние титрируемой кислотности сливок на физико-химические показатели творожного продукта после смешивания с сливками.

Для проведения опыта творожное зерно смешали со сливками с 10,0\%-й массовой долей жира и с титрируемой кислотностью, составляющей соответственно $20 \pm 2,30 \pm 2,40 \pm 2^{\circ} \mathrm{T}$.

Изменения физико-химических параметров творожного продукта были определены через 2 ч после смешивания со сливками.

Влияние титрируемой кислотности на физико-химические параметры творожного продукта представлено в табл. 3.

Табл. 3 показывает, что биохимические процессы более активны во время ферментации творожного зерна в сливках с кислотностью $40 \pm 2^{\circ} \mathrm{T}$.
Процесс ферментации протекает намного медленнее в сливках с кислотностью $20 \pm 2$ и $30 \pm 2{ }^{\circ} \mathrm{T}$.

Титрируемая кислотность ферментационной среды влияет на органолептические показатели готового продукта, которая представлена в табл. 4.

Учитывая количественный рост бактерий кисломолочного продукта, кислотность, а также органолептические показатели, утвердилось оптимальное значение титрируемой кислотности сливок $30 \pm 2^{\circ} \mathrm{T}$.

\section{СПИСОК ЛИТЕРАТУРЫ}

1. Барабанщиков Н.В. Качество молока и молочных продуктов. - М. Колос, 1980. - 255 с.

2. Богданова Г.И. Домашний сыр. - М.: Пищ. промсть, 1979. - 85 с.

3. Горбатова К.К. Биохимия молока и молочных продуктов. - СПб; ГИОРД, 2003. - 320 с.

4. Зобкова 3.С., Щербакова С.А. Производство и 
пути повышения качества творога // Молочная промышленность. - 2006. - № 7. - С. 47.

5. Состав и свойства молока как сырья для молочной промышленности / Н.Ю. Алексеева [и др.]; под ред. Н.Ю. Костина. - М.: Агропромиздат, 1986. - 239 с.

Галстян Бардух Сарибекович, канд. техн. наук, старший преподаватель, Шушинский технологический университет. Республика Армения.

Республика Армения, г. Шуши, ул. Ашота Бекора, 4.

Тел.: +374 47731022 .

Ключевые слова: зернистый творог; сыр; сывороточный белок; бактерии; сычужный фермент.

\title{
THE STUDY OF GRANULAR COTTAGE CHEESE IN THE PROCESS OF FERMENTATION
}

Galstyan Bardukh Saribekovich, Candidate of Technical Sciences, Senior Teacher, Shusha Technological University. Republic of Armenia.

Keywords: granular cottage cheese; cheese; whey protein; bacteria; rennet ferment.
The article is devoted to the use in food purposes of whey and its constituent particles, in particular protein, in order to improve the yield of milk protein, enhance its functional properties, increase the role of protein in human nutrition.

\section{удк 631.354.2 \\ РЕЗУЛЬТАТЫ ИССЛЕДОВАНИЙ ДЛИНЫ И ДИАМЕТРА МОЛОТИЛЬНОГО БАРАБАНА ЗЕРНОУБОРОЧНЫХ КОМБАЙНОВ}

\author{
ДЕМИН Евгений Евгеньевич, Саратовский государственный аграрный университет имени \\ Н.И. Вавилова
}

СТАРЦЕВ Александр Сергеевич, Саратовский государственный аграрный университет имени Н.И. Вавилова

АНАНЬЕВ Вячеслав Андреевич, Саратовский государственный аграрный университет имени Н.И. Вавилова

МАВЗОВИН Владимир Святославович, Саратовский государственный аграрный университет имени Н.И. Вавилова

В результате исследований величин технических характеристик зерноуборочных комбайнов отечественных и зарубежных моделей и модификаций проанализированы значения длины и диаметра молотильного барабана комбайнов. Получены теоретические и эмпирические законы рядов распределений, математическое ожидание, среднеквадратичное отклонение, коэффициент вариации, доверительный интервал среднего значения, 95\%-й размах распределения длины и диаметра молотильного барабана зерноуборочных комбайнов и коэффициента длины молотильного барабана по диаметру.

Введение. Повышение технического и технологического уровня зерноуборочных комбайнов одно из основных направлений их развития [5]. При исследовании технических характеристик комбайнов (номинальной мощности установленного двигателя, массы без жатки, площади решет и соломотряса, длины молотильного барабана, объема бункера) установлены зависимости между их основными показателями $[1,2,9,10]$.

Цель исследования - совершенствование технических средств и технологических процессов зерноуборочных комбайнов.

Методика исследований. Особое значение в технологическом процессе зерноуборочного комбайна имеют длина и диаметр молотильного барабана $[3,6,7,11]$. Нами были поставлены задачи исследовать значение длины и диаметра молотильного барабана комбайнов и получить законы их распределения; определить отношение длины барабана к его диаметру для различ- ных моделей и модификаций зерноуборочных комбайнов отечественных и зарубежных производителей.

При этом мы ввели новое техническое понятие - коэффициент длины молотильного барабана по диаметру:

$$
\psi_{L D}=L_{\sigma} / D_{\text {б }},
$$

где $L_{6}$ - длина молотильного барабана, мм; $D_{6}-$ диаметр молотильного барабана, мм.

Для решения задач собраны технические характеристики зерноуборочных комбайнов ведущих мировых производителей сельскохозяйственной техники и определены численные значения коэффициента $\psi_{L D}$ (табл. 1$)$. 